\title{
CONSTITUTIONALE
}

Volume 1 Issue 1, January-June 2020: PP: 47-56

Faculty of Law, Universitas Lampung, Bandar Lampung, Indonesia.

http://jurnal.fh.unila.ac.id/index.php/constitutionale

P-ISSN: 2723-2492

E-ISSN: $2745-9322$

\section{Validitas Peraturan Pelaksana Undang-Undang Nomor 7 Tahun 2004 tentang Sumber Daya Air Pasca Putusan Mahkamah Konstitusi Nomor: 85/Puu-Xi/2013}

\author{
Validity of the Implementing Regulations of Law Number 7 of 2004 \\ concerning Water Resources Post-Constitutional Court Decision Number 85 / \\ Puu-Xi / 2013
}

\author{
Muhammad Fauzul Adzim \\ fauzuladzim10@gmail.com \\ Lembaga Bantuan Hukum Panglima Tubagus Buang
}

Submitted: Apr 13, 2020; Reviewed: Apr 30, 2020; Accepted: Mei 18, 2020

\begin{tabular}{|c|c|}
\hline Info Artikel & Abstrak \\
\hline $\begin{array}{l}\text { Kata Kunci: Validitas; Putusan Mahkamah } \\
\text { Konstitusi. } \\
\text { Keywords: Validity; Constitutional Court } \\
\text { Decision. }\end{array}$ & $\begin{array}{l}\text { Kekuatan hukum norma peraturan } \\
\text { perundang-undangan } \\
\text { undabawah } \\
\text { rujukannya dapat dibatalkan oleh } \\
\text { Mahkamah Konstitusi. Kekuatan }\end{array}$ \\
\hline $\begin{array}{l}\text { DOI: } \\
\text { https://doi.org/10.25041/constitutionale.v1i1.2012 }\end{array}$ & $\begin{array}{l}\text { hukum norma peraturan pelaksana } \\
\text { dari Undang-Undang Nomor } 7 \\
\text { Tahun } 2004 \text { tentang Sumber Daya } \\
\text { Air dapat ditentukan validitasnya } \\
\text { melalui norma hukum yang lebih } \\
\text { tinggi di atasnya karena norma yang } \\
\text { lebih tinggi akan berujung pada } \\
\text { norma dasar yang menjadi sumber } \\
\text { bagi norma-norma hukum } \\
\text { dibawahnya. Pun halnya dengan } \\
\text { peraturan pelaksana dari sebuah } \\
\text { undang-undang aliditasnya } \\
\text { ditentukan oleh norma hukum } \\
\text { diatasnya secara keseluruhan } \\
\text { maupun per pasal karena norma }\end{array}$ \\
\hline
\end{tabular}


hukum keatas bersumber dan kebawah sebagai sumber. Sesuai dengan teori yang dikemukakan Adolf Merkel dalam teori pertingkatan hukum, yang menyatakan bahwa suatu norma hukum memiliki dua wajah das Doppelte Rechtsanlitz. Adolf mengungkapkan bahwa suatu norma itu ke atas sebagai sumber dan dasar bagi norma hukum dibawahnya. Maka, peraturan pelaksana dari undang-undang Nomor 7 Tahun 2004 tentang Sumber Daya Air akan hilang validitasnya di saat norma sumbernya sudah dibatalkan oleh Mahkamah Konstitusi sehingga diperlukan perubahan terhadap Undang-Undang Nomor 12 Tahun 2011 tentang Pembentukan Peraturan Perundang-undangan yang dilakukan oleh DPR dan Presiden.

Abstract
The power of law of statutory norms
under the law after the reference
regulation can be canceled by the
Constitutional Court. The validity of
the legal strength of implementing
regulations from Law Number 7 of
2004 concerning Water Resources
can be determined through a higher
legal norm above it because a
higher norm will lead to a basic
norm which becomes the source of
the legal norms under it. Likewise
with implementing regulations of a
law, the validity of which is
determined by the legal norms
above it as a whole or per article
because the legal norms above are
sourced and lowered as sources. In
accordance with the theory put
forward by Adolf Merkel in the
theory of legal ranking, which states
that a legal norm has two faces, das
Doppelte Rechtsanlitz. Adolf


revealed that a norm is upward as a source and basis for legal norms underneath. Thus, the validity of the implementing regulations of Law Number 7 of 2004 concerning Water Resources will lose its validity when the source norms have been canceled by the Constitutional Court so that amendments to Law Number 12 of 2011 concerning the Formation of Laws and Regulations by the DPR and President.

\section{A. Pendahuluan}

Tahun 2013 merupakan langkah awal pemerintah bersama legislative memperbaiki peraturan tentang sumber daya air yakni Undang-Undang Nomor 7 Tahun 2004 tentang Sumber Daya Air. Melalui pengujian yang dilakukan Mahkamah Konstitusi terhadap pengujian Undang-Undang Nomor 7 Tahun 2004 tentang Sumber Daya Air terhadap UndangUndang Dasar Negara Republik Indonesia Tahun 1945 dimana pihak pemohon merasa pemerintah lalai dan tidak total bertanggungjawab terhadap pengelolaan seumber daya air. Akibatnya, pihak swasta berpeluang lebih besar menguasai sektor sumber daya air sehingga membuka peluang bagi investor asing menguasai sektor sumber daya air. Perlu diketahui, tahun 2013 lalu dikeluarkan Putusan Mahkamah Konstitusi Nomor 85/PUU-XI/2013 yang menyatakan Undang-Undang Nomor 7 Tahun 2014 tentang Sumber Daya Air bertentangan dengan Undang-Undang Dasar Negara Republik Indonesia Tahun 1945. ${ }^{1}$

Pengujian undang-undang merupakan suatu wewenang untuk menilai apakah suatu undang-undang rumusan muatannya berkesesuaian atau justru bertentangan dengan undangundang dasar serta apakah suatu kekuasaan tertentu berhak mengeluarkan suatu peraturan. ${ }^{2}$ Wewenang untuk menilai produk hukum sebuah peraturan dari cara-cara (procedure) sebagaimana telah ditentukan dalam peraturan perundang-undangan melalui pengujian di Mahkamah Konstitusi baik melalui uji formil maupun materiil. ${ }^{3}$ Pengujian formal biasanya terkait dengan soal-soal prosedural dan berkenaan dengan legalitas kompetensi institusi pembuatnya disebut dengan pengujian formal dan wewenang untuk menyelidiki serta menilai apakah suatu peraturan perundang-undangan sesuai atau bertentangan dengan peraturan yang lebih tinggi, serta apakah suatu kekuasaan tertentu (verordenende macht) berhak mengeluarkan suatu peraturan tertentu pengujian ini disebut pengujian materiil. ${ }^{4}$

Pengujian kembali dapat dilakukan pemerintah, legislatif serta lembaga yudikatif dalam hal pengujian formil..$^{5}$ Dalam hal upaya peninjauan atau pengujian kembali yang dilakukan pemerintah dinamakan executif review, sedangkan pengujian legislatif dinamakan legislatif

\footnotetext{
${ }^{1}$ Izzatin Kamala, "Harapan Baru Atas Pengelolaan Sumber Daya Air Terkait Putusan MK Nomor 85/PUU-XI/2013," Jurnal Konstitusi 12, no. 3 (2016): 422-46, https://doi.org/10.31078/jk1231.

${ }^{2}$ Taufiqurrohman Syahuri, Hukum Konstitusi, (Jakarta: Ghalia Indonesia, 2004), hlm. 49 ,

${ }^{3}$ Mohammad Mahrus Ali, Meyrinda Rahmawaty Hilipito, and Syukri Asy'ari, "Tindak Lanjut Putusan Mahkamah Konstitusi Yang Bersifat Konstitusional Bersyarat Serta Memuat Norma Baru,” Jurnal Konstitusi 12, no. 3 (2016): 631-62, https://doi.org/10.31078/jk12310.

4 N. Nurhidayatuloh, "Dilema Pengujian Undang-Undang Ratifikasi Oleh Mahkamah Konstitusi Dalam Konteks Ketetanegaraan Ri," Jurnal Konstitusi 9, no. 1 (2012): 116-25, https://doi.org/10.31078/jk.

5 Adrian Faridhi, "Penguji Peraturan Perundang-Undangan Tunggal Keniscayaan," JURNAL MERCATORIA 10, no. 2 (2017): 180-96, https://doi.org/10.31289/mercatoria.v10i2.1202.
} 
review dan pengujian yang dilakukan yudikatif disebut judicial review. ${ }^{6}$ Undang-Undang Dasar Negara Republik Indonesia Tahun 1945 hanya memberikan kewenangan kepada Mahkamah Konstitusi untuk menguji undang-undang terhadap UUD 1945, ${ }^{7}$ Pasal 24C ayat (1) mengatur kewenangan Mahkamah Konstitusi yakni "Mahkamah Konstitusi berwenang mengadili pada tingkat pertama dan terakhir yang putusannya bersifat final untuk menguji undang-undang terhadap undang-undang dasar, memutus sengketa kewenangan lembaga negara, memutus pembubaran partai politik dan memutus perselisihan tentang pemilu". Sementara itu, kewenangan pengujian peraturan perundang-undangan dibawah undangundang terhadap undang-undang diberikan kepada Mahkamah Agung. ${ }^{8}$ Sebagaimana pengaturan pasal 24 A ayat 1 Undang-Undang Dasar 1945 bahwa Mahkamah Agung berwenang mengadili pada tingkat kasasi, menguji peraturan perundang-undangan di bawah undang-undang terhadap undang-undang, dan mempunyai wewenang lain yang diberikan oleh Undang-Undang.

Peraturan pemerintah, peraturan presiden, dan peraturan daerah jelas merupakan peraturan yang tingkatannya berada dibawah undang-undang yang kewenangan pengujianya oleh Mahkamah Agung. Jika yang diuji undang-undang maka batu ujinya haruslah undangundang dasar yang merupakan kewenangan Mahkamah Konstitusi, bukan Mahkamah Agung. Peraturan daerah merupakan salah satu bentuk peraturan yang dibawah undang-undang dan karena itu dapat diuji oleh Mahkamah Agung, bukan oleh Mahkamah Konstitusi. ${ }^{9}$ Namun demikian, peraturan daerah bukanlah produk regulatif dan executive act seperti halnya undang-undang. ${ }^{10}$ Perlu dibedakan antara kewenangan pengujian undang-undang terhadap undang-undang dasar yang merupakan kewenangan Mahkamah Konstitusi, dengan pengujian peraturan perundang-undangan di bawah undang-undang terhadap undang-undang yang merupakan kewenangan Mahkamah Agung. Dengan adanya pembedaan tersebut, sering dibedakan antara Mahkamah Konstitusi adalah pengawal undang-undang dasar (The guardiant of constitutions), sedangkan Mahkamah Agung adalah pengawal undang-undang (The guardiant of law). Hak uji materiil yang dimiliki Mahkamah Konstitui berfungsi sebagai pengawal konstitusi negara indonesia (The guardiants Of Constitusional) agar terjaga dari norma-norma yang menyimpang dari dasar negara (Staat Grund Gesetz) yaitu UndangUndang Dasar Negara Republik Indonesia 1945.

Pasal 51 ayat (3) huruf b Undang-Undang Nomor 24 Tahun 2003 tentang Mahkamah Konstitusi menyatakan bahwa uji materiil dengan mana materi muatan ayat, pasal atau bagian undang-undang yang dianggap bertentangan dengan Undang-Undang Dasar 1945 dapat diminta untuk dinyatakan tidak mempunyai kekuatan mengikat secara hukum. Diuji pun hanya pada ayat, pasal tertentu atau bagian undang-undang lainnya yang di anggap bertentangan dengan konstitusi dan karenanya dimohon tidak mempunyai kekuatan mengikat. Bahkan dalam putusan Mahkamah Konstitusi, ada yang menyatakan satu pasal bertentangan dengan Undang-Undang Dasar 1945, tetapi dengan membuang kata yang merupakan bagian kalimat dalam pasal tersebut makna pasal tersebut dapat berubah sama sekali dan dipandang dengan demikian tidak lagi bertentangan dengan Undang-Undang Dasar 1945. ${ }^{11}$ Ada kalanya

\footnotetext{
${ }^{6}$ Fatmawati, Hak Menguji (Toetsingrecht), (Jakarta: PT. RajaGrafindo Persada, 2006) hlm. IX

7 Janpatar Simamora, "Legal Dynamics And Implementation Problems Of Judicial Review Authority In The Supreme Court," Jurnal Dinamika Hukum 16, no. 2 (2016): 179-86, https://doi.org/10.20884/1.jdh.2016.16.2.490.

8 , Achmad and , Mulyanto, "Problematika Pengujian Peraturan Perundang-Undangan (Judicial Review) Pada Mahkamah Agung Dan Mahkamah Konstitusi," Yustisia Jurnal Hukum 2, no. 1 (2013): 57-65, https://doi.org/10.20961/yustisia.v2i1.11070.

${ }^{9}$ Victor Imanuel Williamson Nalle, "Hak Menguasai Negara Atas Mineral Dan Batubara Pasca Berlakunya Undang-Undang Minerba," JurnaI Konstitusi 9, no. 3 (2012): 480, https://doi.org/10.31078/jk\%x.

${ }^{10}$ Jimli ashhidiqi, Hukum Acara Pengujian Undang-Undang, (Jakarta: penerbit konstitusi press, 2006) hlm. 45.

${ }^{11}$ Maruarar Siahaan, Hukum Acara Mahkamah Konstitusi Republik Indonesia, (Jakarta: Sinar Grafika, 2011), hlm.21
} 
dari keseluruhan undang-undang yang diuji hanya beberapa pasal saja yang dianggap bertentangan dengan Undang-Undang Dasar 1945. Namun, pasal tersebut merupakan pasal yang menjadi jiwa atau roh dari undang-undang tersebut, yang mempengaruhi keseluruhan keberlakuan undang-undang tersebut. ${ }^{12}$ Apabila suatu undang-undang dilihat dari isinya bertentangan dengan undang-undang dasar, maka undang-undang tersebut harus dinyatakan tidak mempunyai daya mengikat. Sebuah undang-undang yang sudah tidak memiliki daya ikat akan berakibat pada peraturan di bawahnya sesuai dengan hieraki perundang-undangan yang ada di negara indonesia. Seperti persoalan di batalkannya secara keseluruhan Undang-Undang Nomor 7 Tahun 2004 tentang Sumber Daya Air. Pembatalannya secara keseluruhan akan berakibat kepada status norma peraturan perundang-undangan di bawahnya. Setelah Mahkamah Konstitusi membatalkan suatu undang-undang karena telah bertentangan dengan undang-undang dasar maka akan terjadi dua permasalahan. Pada saat undang-undang di batalkan oleh Mahkamah Konstitusi baik secara keseluruhan atau satu pasal, maka akan berimplikasi terhadap status norma peraturan-peraturan pelaksana yang ada di bawahnya.

Berdasarkan pemikiran tersebut, penulis meneliti berbagai peraturan pemerintah dengan batu uji berupa risalah putusan Mahkamah Konstitusi Perkara Nomor 85/PUU-XI/2013 mengenai kekuatan hukum Peraturan Pemerintah Republik Indonesia Nomor 16 Tahun 2005 tentang Pengembangan Sistem Penyediaan Air Minum, Peraturan Pemerintah Republik Indonesia Nomor 42 Tahun 2008 tentang Pengelolaan Sumber Daya Air, Peraturan Pemerintah Nomor 20 tentang Irigasi, Peraturan Pemerintah Nomor 43 Tahun 2008 tentang Air tanah, Peraturan Pemerintah Nomor 38 Tahun 2011 tentang Sungai, Peraturan Pemerintah Nomor 73 Tahun 2013 tentang rawa, Peraturan Pemerintah Nomor 69 Tahun 2014 tentang Hak Guna Air setelah Mahkamah Konstitusi membatalkan Undang-Undang Nomor 7 Tahun 2004 tentang Sumber daya Air secara keseluruhan. Rumusan masalah yang dibahas yakni bagaimana kekuatan hukum norma peraturan pelaksana dari Undang-Undang Nomor 7 Tahun 2004 tentang Sumber Daya Air setelah undang-undang rujukanya dibatalkanoleh Mahkamah Konstitusi. Jenis penelitian menggunakan hukum normatif dan menggunakan pendekatan pendekatan undang-undang (statute approach), pendekatan kasus (case approach), dan pendekatan konseptual (conseptual approach).

\section{B. Pembahasan}

1. Kekuatan Hukum Norma Peraturan Pelaksana Dari Undang-Undang Nomor 7 Tahun 2004 Tentang Sumber Daya Air Pasca Peraturan Rujukan Dibatalkan Oleh Mahkamah Konstitusi

Sektor sumber daya air sebelum Undang-Undang Nomor 7 Tahun 2004 tentang Sumber Daya Air (selanjutnya akan disebut UU SDA) disahkan, pengaturannya terdapat dalam Undang-Undang Nomor 11 Tahun 1974 tentang Perairan (selanjutnya disebut UU Pengairan), Namun, seiring dengan perkembangan zaman dan adanya perubahan-perubahan yang cepat dalam tatanan kehidupan masyarakat (globalisasi, perubahan kebijakan ekonomi dan politik) maka undang-undang pengairan dirasa sudah tidak lagi memadai sehingga pemerintah membentuk undang-undang SDA. ${ }^{13}$ Undang-undang SDA telah disahkan Dewan Perwakilan Rakyat pada tanggal 18 maret 2004, namun banyak kalangan mengecam undang-undang tersebut karena mengandung unsur privatisasi dan itu akan berdampak pada di

\footnotetext{
${ }^{12}$ Ibid, hlm 23

${ }^{13}$ Sulthan Zainuddin et al., "Kontestasi Kekuasaan Dalam Pengelolaan SDA,” Jurnal Academica Fisip Untad 2, no. 2 (2010): 455-68.
} 
komersialisasikanya air yang merupakan kebutuhan dasar bagi manusia. ${ }^{14}$ Pasal 5 mengatur jika negara memiliki kewajiban untuk menjamin hak atas air bagi setiap orang guna memenuhi kebutuhan minimum sehari-hari yang sehat, bersih dan produktif. Namun pada pasal-pasal berikutnya tidak ditemukan mekanisme yang hendak ditempuh negara agar jaminan negara sebagaimana diamanatkan Pasal $A$ Quo terwujud. ${ }^{15}$ Sistem hak atas air juga terdapat dalam Pasal 7 yang menyebutkan bahwa hak guna air meliputi hak guna pakai air dan hak guna usaha air. Kemudian ditegaskan bahwa hak guna air tersebut tidak dapat disewakan atau dipindahtangankan baik sebagian maupun seluruhnya. Jika berhenti pada ayat ini maka terlihat jika hak menguasai sumber daya air yang di miliki oleh negara (Pasal 6).

Maka hak tersebut tidak dapat disewakan ataupun di pindahtangankan. Dengan demikian, seharusnya pemerintah dalam pengelolaan sumber daya air harus mementingkan sebesarbesarnya kemakmuran rakyat dan tidak boleh menyewakan atau memindahtangankan baik sebagian maupun seluruhnya hak guna air yang dimilikinya. ${ }^{16}$ Pasal 9 A Quo menyebutkan kemungkinan pemberian izin kepada perseorangan untuk memiliki hak guna usaha air. Seyogyanya pemerintah tidak sekedar memberikan izin atas hak tersebut, namun tetap dalam kerangka kerjasama antara pemerintah dan pihak ketiga. Hal itupun tetap disertai catatan bahwa kewajiban utama yang dimiliki pemerintah sebagai pemegang hak guna air adalah memenuhi amanat pasal 5 undang-undang ini. Berdasarkan hal tersebut, kegiatan untuk menguasai sumber daya air dan memanfaatkannya demi kerpentingan pribadi menjadi sah atas nama hukum. ${ }^{17}$ Water right juga mendukung upaya-upaya untuk melihat nilai ekonomis dari air sehingga dijadikan komoditi. Dengan kata lain, water right sangat mendukung terjadinya komodifikasi air ditambah undang-undang SDA yang di maksudkan untuk menjalankan program reformasi air Bank Dunia yang telah dicanangkan sejak 1992, berbasis pada Dublin Statement (Ibnu Sina Chandranegara, 2015).

Paradigma pengelolaan sumber air yang dijelaskan diatas terdapat kesalahan mendasar undang-undang SDA terhadap Undang-Undang Dasar 1945 yakni air dipandang sebagai barang ekonomi dengan diperkenalkannya hak guna air yang terdiri dari hak guna pakai dan hak guna usaha dan penyelenggaraan oleh Swasta (Privatisasi). Hal tersebut yang menjadi dasar Mahkamah Konstitusi (MK) membatalkan seluruh pasal dalam undang-undang SDA pada tanggal 18 Februari 2015 melalui putusan MK Nomor 85/ PUU-XI/2013. Kebijakan terhadap undang-undang tersebut di anggap belum menjamin pembatasan pengelolaan air oleh pihak swasta sehingga dinilai bertentangan dengan UUD 1945. Guna menghindari terjadinya kekosongan hukum yang berakibat terjadinya kekacauan hukum, maka MK memberlakukan kembali undang-undang pengairan hingga adanya pembentukan undangundang yang baru. ${ }^{18}$ Hal ini tentu saja berpengaruh terhadap proses pengelolaan air terlebih jika dasar yuridis yang digunakan perusahan swasta dalam mengelola sumber saya air selama ini telah dibatalkan sehingga peusahaan swasta kehilangan kekuatan hukum dalam pelaksanaan pengelolaan air. Undang-Undang Sumber Daya Air yang dibatalkan oleh

\footnotetext{
14 , AL. Sentot Sudarwanto, "Dampak Dibatalkannya Undang-Undang Nomor 7 Tahun 2004 Tentang Sumber Daya Air Terhadap Manajemen Air Untuk Kesejahteraan Masyarakat," Yustisia Jurnal Hukum 92, no. 1 (2015), https://doi.org/10.20961/yustisia.v92i0.3828.

15 Helmi Kasim, "Penegasan Peran Negara Dalam Pemenuhan Hak Warga Negara Atas Air," Jurnal Konstitusi 12, no. 2 (2016): 353-72, https://doi.org/10.31078/jk1228.

16 Ria Casmi Arrsa, "Indikasi Kriminalisasi Pembela Ham Dalam Sengketa Agraria Kajian Putusan Nomor 250.Pid.B.2013/PN.PLG Dan Nomor 76/PID/2013/PT.PLG,”Jurnal Yudisial 7, no. 1 (2014): 53-69.

${ }^{17}$ Santi Puspitasari et al., "Reaksi Transfer Hidrogenasi Minyak Jarak Kastor Serta Aplikasinya Sebagai Bahan Pelunak Kompon Karet," Majalah Kulit, Karet, Dan Plastik 32, no. 2 (2016): 85-98, https://doi.org/10.20543/mkkp.v32i2.1361.

${ }^{18}$ Irfan Nur Rachman, "Politik Hukum Pengelolaan Sumber Daya Alam Menurut Pasal 33 UUD 1945," Jurnal Konstitusi 13, no. 1 (2016): 191-212, https://doi.org/10.31078/jk1319.
} 
Mahkamah Konstitusi ini membuat aturan-aturan yang ada dibawahnya tidak berlaku. Beberapa aturan yang dibuat oleh pemerintah untuk melaksanakan UU SDA, diantaranya:

a. Peraturan Pemerintah Nomor 16 Tahun 2005 tentang Pengembangan Sistem Penyediaan Air Minum;

b. Peraturan Pemerintah Nomor 20 Tahun 2006 tentang irigasi;

c. Peraturan Pemerintah Nomor 42 Tahun 2008 tentang Pengelolaan Sumber Daya Air;

d. Peraturan Pemerintah Nomor 43 Tahun 2008 tentang air tanah;

e. Peraturan Pemerintah Nomor 38 Tahun 2011 tentang sungai;

f. Peraturan pemerintah Nomor 73 Tahun 2013 tentang Rawa;

g. Peraturan Pemerintah Nomor 69 Tahun 2014 tentang Hak Guna Air.

Peraturan-peraturan pelaksana di atas merupakan peraturan di bawah undang-undang sumber daya air yang dibatalkan oleh Mahkamah Konstitusi sehingga berakibat terhadap segala peraturan dibawahnya. ${ }^{19}$ Ini sesuai dengan landasan teori mengenai hierarki peraturan perundang-undangan serta merujuk pada sebuah teori yang di sampaikan oleh Adolf merkel yang telah mengemukakan bahwa suatu norma itu ke atas menjadi sumber dan dasar bagi norma hukum dibawahnya, sehingga norma hukum mempunyai masa berlaku yang relatif, oleh karena masa berlakunya suatu norma hukum itu tergantung pada norma hukum yang berada diatasnya. ${ }^{20}$ Teori Adolf Merkel tersebut disempurnakan oleh Hans Kelsen melalui teori stufentheori. Hans Kelsen memberikan penjelasan lebih lanjut tentang stufenteorie tersebut sebagai berikut:" "Suatu norma yang validitasnya tidak dapat diperoleh dari norma lain yang lebih tinggi, disebut sebagai norma dasar, semua norma yang validitasnya dapat ditelusuri kepada suatu norma dasar yang sama membentuk suatu sistem norma. Norma dasar yang menjadi sumber utama ini merupakan pengikat diantara semua norma yang berbeda-beda yang membentuk suatu tata norma. Bahwa suatu norma termasuk kedalam suatu sistem norma tertentu, dapat diuji hanya dengan penegasan bahwa norma tersebut memperoleh validitasnya dari norma dasar yang membentuk sistem norma tersebut". ${ }^{22}$

Melihat kepada kasus yang terjadi pada pembatalan norma Undang-Undang Sumber Daya Air ini mengakibatkan peraturan pelaksana yang menjadi dasar pelaksanaan di lapangan terhadap seluruh norma Undang-Undang Sumber Daya Air menjadi tidak berlaku diakibatkan validitas norma peraturan pelaksana telah hilang dengan dibatalakannya norma dasar yang membentuk norma pelaksana tersebut. Norma dasar yang membentuk norma terhadap validitas peraturan yang ada dibawahnya sesuai dengan jenjang peraturan perundangundangan negara indonesia. Peraturan perundang-undangan di indonesia diatur dalam pasal 7 ayat (1) Undang-Undang Nomor 12 Tahun 2011 mengenai hierarki peraturan perundangundangan sebagai berikut:

1) Undang-Undang Dasar Negara Republik Indonesia 1945;

2) Ketetapan MPR;

3) Undang-Undang / peraturan pemerintah pengganti undang-undang;

4) Peraturan Pemerintah;

5) Peraturan Presiden;

6) Peraturan Daerah Provinsi dan;

\footnotetext{
${ }^{19}$ Amrizal J. Prang, "Implikasi Hukum Putusan Mahkamah Konstitusi,” Kanun: Jurnal Ilmu Hukum 13, no. 1 (2011): 77-94, https://doi.org/10.24815/kanun.v13i1.6233.

${ }^{20}$ Ibid, hlm. 42

${ }^{21}$ Hans Kelsen, Teori Hukum Murni: Dasar-Dasar Ilmu Hukum Normatif sebagai Ilmu Hukum Empirik-Deskriptif, (The Pure Theorie Of Law). Di terjemahkan oleh soemardi, Cet3.ed revisi (Jakarta: Bee Media, 2007), hlm. 138-139.

22 SUWARDI SAGAMA, "Reformulasi Hierarki Peraturan Pada Pembentukan Peraturan Perundang-Undangan Di Indonesia," Volksgeist: Jurnal Ilmu Hukum Dan Konstitusi 1, no. 2 (2018): 185-97, https://doi.org/10.24090/volksgeist.v1i2.1967.
} 
7) Peraturan Daerah Kabupaten/Kota.

Melihat hierarki peraturan perundang-undangan diatas peraturan pelaksana di bawah Undang-Undang Sumber Daya Air merupakan dalam bentuk peraturan pemerintah yang secara hierarki terdapat dibawah Undang-Undang sebagai peraturan diatasnya yang merupakan sumber validitas untuk peraturan pelaksananya sesua denga teori yang telah dikemukakan di atas. Undang-Undang Nomor 8 Tahun 2011 tentang Perubahan Atas Undangundang Nomor 24 Tahun 2003 tentang Mahkamah Konstitusi menyatakan bahwa Mahkamah Konstitusi dilarang membuat keputusan Ultra Petita Partium. ${ }^{23}$ Hakim tidak boleh memberi putusan tentang sesuatu yang tidak dituntut atau tidak diminta dalam petitum atau mengabulkan lebih dari pada yang dituntut oleh penggugat, tetapi hakim tidak dilarang memberi putusan yang mengurangi isi dari tuntutan gugatan. Landasanya adalah pasal 178 ayat $3 \mathrm{HIR}$, dan pasal 189 ayat $3 \mathrm{R} . \mathrm{Bg}$. pengguggat hanya memohon agar Mahkamah Konstitusi menyatakan undang-undang sumber daya air bertentangan dengan Undang-Undang Dasar 1945 dan undang-undang sumber daya air dinyatakan tidak mempunyai kekuatan hukum mengikat secara keseluruhan. Karenanya, Mahkamah Konstitusi hanya memasukan keenam peraturan pemerintah tersebut kedalam bahan pertimbangan putusan ${ }^{24}$ Mahkamah Konstitusi dan dalam amar putusan hanya memutuskan sesuai dengan yang dimohonkan oleh pengguggat. Bahkan pertimbangan dan amar putusan merupakan satu kesatuan yang tidak dipisahkan, sehingga peraturan pemerintah yang telah terbit sebagai aturan pelaksana undangundang sumber daya air menjadi tidak memiliki kekuatan hukum mengikat.

\section{Kesimpulan}

Kekuatan hukum norma peraturan pelaksana dari Undang-Undang Nomor 7 Tahun 2004 tentang Sumber Daya Air dapat ditentukan validitasnya melalui norma hukum yang lebih tinggi di atasnya, norma yang lebih tinggi akan berujung pada norma dasar yang menjadi sumber bagi norma-norma hukum dibawahnya. Pun halnya dengan peraturan pelaksana dari sebuah undang-undang, peraturan pelaksana di bawah undang-undang validitasnya ditentukan oleh norma hukum diatasnya, baik secara keseluruhan maupun perpasal, karena norma hukum keatas bersumber dan kebawah sebagai sumber. Oleh karena itu, peraturan pelaksana dari Undang-Undang Nomor 7 Tahun 2004 tentang Sumber Daya Air akan otomatis hilang validitasnya di saat norma sumbernya sudah dibatalkan oleh Mahkamah Konstitusi. Penulis memberikan saran jika Mahkamah Konstitusi mampu memberikan sosialisasi dan penjelasan lebih masif lagi kepada seluruh masyarakat dan lembaga negara lainnya terkait undangundang yang menjadi dasar bagi peraturan pelaksana yang sedang di lakukan uji materiil sehingga tidak mengakibatkan kesalahpahaman implementasi dan perlakuan terhadap peraturan pelaksana yang ada di bawah undang-undang tersebut. Lalu menjamin terjaganya harmonisasi peraturan perundang-undangan dan terciptanya kepastian hukum terhadap peraturan pelaksanan dari undang-undang yang sudah dibatalkan oleh Mahkamah Konstitusi, maka di dalam Undang-Undang Nomor 12 Tahun 2011 tentang Pembentukan Peraturan Perundang-undangan perlu diatur mengenai penjelasan terhadap validitas peraturan pelaksana yang undang-undang rujukannya telah dibatalkan oleh Mahkamah Konstitusi, oleh karena itu perlu perubahan terhadap Undang-Undang Nomor 12 Tahun 2011 tentang Pembentukan Peraturan Perundang-undangan yang dilakukan oleh DPR dan Presiden.

\footnotetext{
${ }^{23}$ Bambang Sugeng Ariadi Subagyono, Johan Wahyudi, and Razky Akbar, "Kajian Penerapan Asas Ultra Petita Pada," Yuridika 29, no. 1 (2014): 100-112, https://doi.org/10.20473/ydk.v29i1.360.

${ }_{24}$ Muhammad Habibi, "Independensi Kewenangan Komisi Pemberantasan Korupsi Pasca Perubahan Undang-Undang Nomor 30 Tahun 2002 Tentang Komisi Pemberantasan Korupsi,” Cepalo 4, no. 1 (2020): 38-47, https://doi.org/10.25041/cepalo.v4no1.1962.
} 


\section{Daftar Pustaka}

A. Buku

Asshiddiqie, Jimly. 2005. Model-Model Pengujian Konstitusional di Berbagai Negara. Jakarta: Konstitusi Press

Hans Kelsen. 2007. Teori Hukum Murni: Dasar-Dasar Ilmu Hukum Normatif sebagai Ilmu Hukum Empirik-Deskriptif, (The Pure Theorie Of Law),Jakarta: Bee Media.

Siahan, Maruarar, 2011. Hukum Acara Mahkamah Konstitusi Republik Indonesia. Jakarta: Sinar Grafika.

Syahuri, Taufiqurrohman. 2004. Hukum Konstitusi. Jakarta: Ghalia Indonesia

B. Jurnal

Achmad, and, Mulyanto. "Problematika Pengujian Peraturan Perundang-Undangan (Judicial Review) Pada Mahkamah Agung Dan Mahkamah Konstitusi." Yustisia Jurnal Hukum 2, no. 1, 2013: 57-65. https://doi.org/10.20961/yustisia.v2i1.11070.

AL. Sentot Sudarwanto. "Dampak Dibatalkannya Undang-Undang Nomor 7 Tahun 2004 Tentang Sumber Daya Air Terhadap Manajemen Air Untuk Kesejahteraan Masyarakat." Yustisia Jurnal Hukum 92, no. 1, 2015. https://doi.org/10.20961/yustisia.v92i0.3828.

Ali, Mohammad Mahrus, Meyrinda Rahmawaty Hilipito, and Syukri Asy'ari. "Tindak Lanjut Putusan Mahkamah Konstitusi Yang Bersifat Konstitusional Bersyarat Serta Memuat Norma Baru.” Jurnal Konstitusi 12, no. 3, 2016: 631-62. https://doi.org/10.31078/jk12310.

Arrsa, Ria Casmi. "Indikasi Kriminalisasi Pembela Ham Dalam Sengketa Agraria Kajian Putusan Nomor 250.Pid.B.2013/PN.PLG Dan Nomor 76/PID/2013/PT.PLG.” Jurnal Yudisial 7, no. 1, 2014: 53-69.

Faridhi, Adrian. "Penguji Peraturan Perundang-Undangan Tunggal Keniscayaan." JURNAL MERCATORIA 10, no. 2, 2017: 180-96. https://doi.org/10.31289/mercatoria.v10i2.1202.

Habibi, Muhammad. "Independensi Kewenangan Komisi Pemberantasan Korupsi Pasca Perubahan Undang-Undang Nomor 30 Tahun 2002 Tentang Komisi Pemberantasan Korupsi." Cepalo 4, no. 1, 2020: 38-47. https://doi.org/10.25041/cepalo.v4no1.1962.

Kamala, Izzatin. "Harapan Baru Atas Pengelolaan Sumber Daya Air Terkait Putusan MK Nomor 85/PUU-XI/2013." Jurnal Konstitusi 12, no. 3, 2016: 422-46. https://doi.org/10.31078/jk1231.

Kasim, Helmi. "Penegasan Peran Negara Dalam Pemenuhan Hak Warga Negara Atas Air." Jurnal Konstitusi 12, no. 2, 2016: 353-72. https://doi.org/10.31078/jk1228.

Nalle, Victor Imanuel Williamson. "Hak Menguasai Negara Atas Mineral Dan Batubara Pasca Berlakunya Undang-Undang Minerba." JurnaI Konstitusi 9, no. 3, 2012: 480. https://doi.org/10.31078/jk\%x.

Nurhidayatuloh, N. "Dilema Pengujian Undang-Undang Ratifikasi Oleh Mahkamah Konstitusi Dalam Konteks Ketetanegaraan Ri." Jurnal Konstitusi 9, no. 1, 2012: 116-25. https://doi.org/10.31078/jk.

Prang, Amrizal J. "Implikasi Hukum Putusan Mahkamah Konstitusi." Kanun: Jurnal Ilmu Hukum 13, no. 1, 2011: 77-94. https://doi.org/10.24815/kanun.v13i1.6233.

Puspitasari, Santi, Adi Cifriadi, Krisnawati Krisnawati, and Tun Tedja Irawadi. "Reaksi Transfer Hidrogenasi Minyak Jarak Kastor Serta Aplikasinya Sebagai Bahan Pelunak Kompon Karet." Majalah Kulit, Karet, Dan Plastik 32, no. 2, 2016: 85-98. https://doi.org/10.20543/mkkp.v32i2.1361.

Rachman, Irfan Nur. "Politik Hukum Pengelolaan Sumber Daya Alam Menurut Pasal 33 UUD 1945." Jurnal Konstitusi 13, no. 1, 2016: 191-212. https://doi.org/10.31078/jk1319.

Sagama, Suwardi. "Reformulasi Hierarki Peraturan Pada Pembentukan Peraturan PerundangUndangan Di Indonesia." Volksgeist: Jurnal Ilmu Hukum Dan Konstitusi 1, no. 2, 2018 : 185-97. https://doi.org/10.24090/volksgeist.v1i2.1967. 
Simamora, Janpatar. "Legal Dynamics And Implementation Problems Of Judicial Review Authority In The Supreme Court." Jurnal Dinamika Hukum 16, no. 2, 2016: 179-86. https://doi.org/10.20884/1.jdh.2016.16.2.490.

Subagyono, Bambang Sugeng Ariadi, Johan Wahyudi, and Razky Akbar. "Kajian Penerapan

Asas Ultra Petita Pada." Yuridika 29, no. 1, 2014: 100-112. https://doi.org/10.20473/ydk.v29i1.360.

Zainuddin, Sulthan, Endriatmo Soetarto, Soeryo Adiwibowo, and Nurmala K Panjaitan. "Kontestasi Kekuasaan Dalam Pengelolaan SDA." Jurnal Academica Fisip Untad 2, no. 2, 2010: 455-68. 